Ludwig, T.D., \& Ludwig, D.J. (2010). Teaching with Purpose: An Interview with Thomas E. Ludwig. Teaching of Psychology, 37 (1), 69-76. (Jan-Mar 2010) Published by Taylor \&Francis (ISSN: 0098- 8023). DOI:

10.1080/00986280903425979

\title{
Teaching With Purpose: An Interview With Thomas E. Ludwig
}

Timothy D. Ludwig and David J. Ludwig

Thomas E. Ludwig is the John Dirk Werkman Professor of Psychology at Hope College, where he joined the faculty in 1977 after receiving his PhD in development and aging from Washington University in St. Louis. His research focuses on developmental issues in cognitive neuropsychology. $\mathrm{He}$ is also the author or coauthor of more than a dozen sets of instructional computer activities, including PsychSim, PsychQuest, PsychOnline, PsychInquiry, Exploring Human Development, ActivePsych, and Concepts in Action. In 2003, Hope College presented him with its Provost's Award for Excellence in Teaching, and in 2005, the American Psychological Foundation honored him with the Charles L. Brewer Distinguished Teaching of Psychology Award.

Timothy D. Ludwig received an MA from Wake Forest University and a PhD in industrial/organizational psychology from Virginia Tech. Since 1994, he has been on faculty at Appalachian State University where he has received the University Deans Distinguished Graduate Faculty Award and the UNC Board of Governors Award for Excellence in Teaching. He is currently the editor of the Journal of 
Organizational Behavior Management and serves on the board of the Organizational Behavior Management National Network. He is the author of dozens of scholarly articles and one book that empirically document the successes of behavioral methods to improve safety and quality in industry.

David J. Ludwig is emeritus professor of psychology at Lenoir-Rhyne University. He received an MDiv from Concordia Seminary, in St. Louis, and a PhD in personality from Washington University in St. Louis. His creative blending of psychology and religion has spanned more than 40 years as a university professor, a licensed psychologist, and a Lutheran minister. During this time, he has authored seven books, several DVD series, and numerous professional articles, while speaking internationally on practical ways to develop healthier personal and family relationships.

Tim: I feel as if we should call this interview "Ludwig and Ludwig on Ludwig" because we're all from the same family. As the "junior generation" in this trio of Ludwig psychologists, let me begin by asking why you decided to enter the field of psychology. I know that my father, Dave Ludwig, your older brother and career academic and practicing psychologist, influenced my decision to go into psychology. What were the formative influences in your life that led you to a career in psychology?

Tom: Looking back on my childhood and adolescence from the perspective of middle age, it seems almost inevitable that I would pursue a career as an educator. l've always loved learning-exploring ideas, finding connections, and gaining a deeper understanding of the world around me. By the time I reached my early teens, I had discovered that I could clearly communicate to others what I had learned, which I found very rewarding. Like you, I also had role models within the family. Although my father and both grandfathers were Christian ministers, many other family members were educators. Two uncles and an aunt were university professors. Three of my sisters became teachers, and two of my brothers-including your father, Dave-recently retired after long academic careers.

Dave: As brothers, we share a family history and a somewhat unusual entry into the field of psychology. I never planned to become a university professor and author. Instead, I began studying to become a Lutheran pastor, following in the footsteps of my father, uncles, 
and three older brothers. But while I was attending the Lutheran seminary in St. Louis, I took several courses in psychology at Washington University. I saw deep connections with my interests in spiritual issues, so I decided to pursue a PhDin psychology instead and have spent my professional life seeking integration of psychology and theology. As your older brother, I watched you grow up, and I thought you were also headed for the ministry. What led you to become a professor of human development instead of a pastor?

Tom: I was never really on track to become a congregational pastor. By the time I left high school, I was already planning a career in postsecondary education, most likely as a professor at a seminary or university. My experiences as a college student fostered a growing sense that I should seek vocation as an educator. My first love was languages, though, and I expected to pursue a PhD in Greek or Hebrew after I finished my pastoral studies. External events in the early 1970s made that path less attractive to me, so I moved to Plan B: psychology. The aspect of psychology that held the most interest for me was gerontology, in part because I was the youngest of 12 siblings. As you know, when I was born, my mother was 45 and my father was 51. My father retired at age 65, when I was in eighth grade, so I spent my high school years in the home of a retired couple. This experience gave me some insight into both the joys and the challenges of the retirement years and later spurred my interest in pursuing a PhD in human development and aging. 


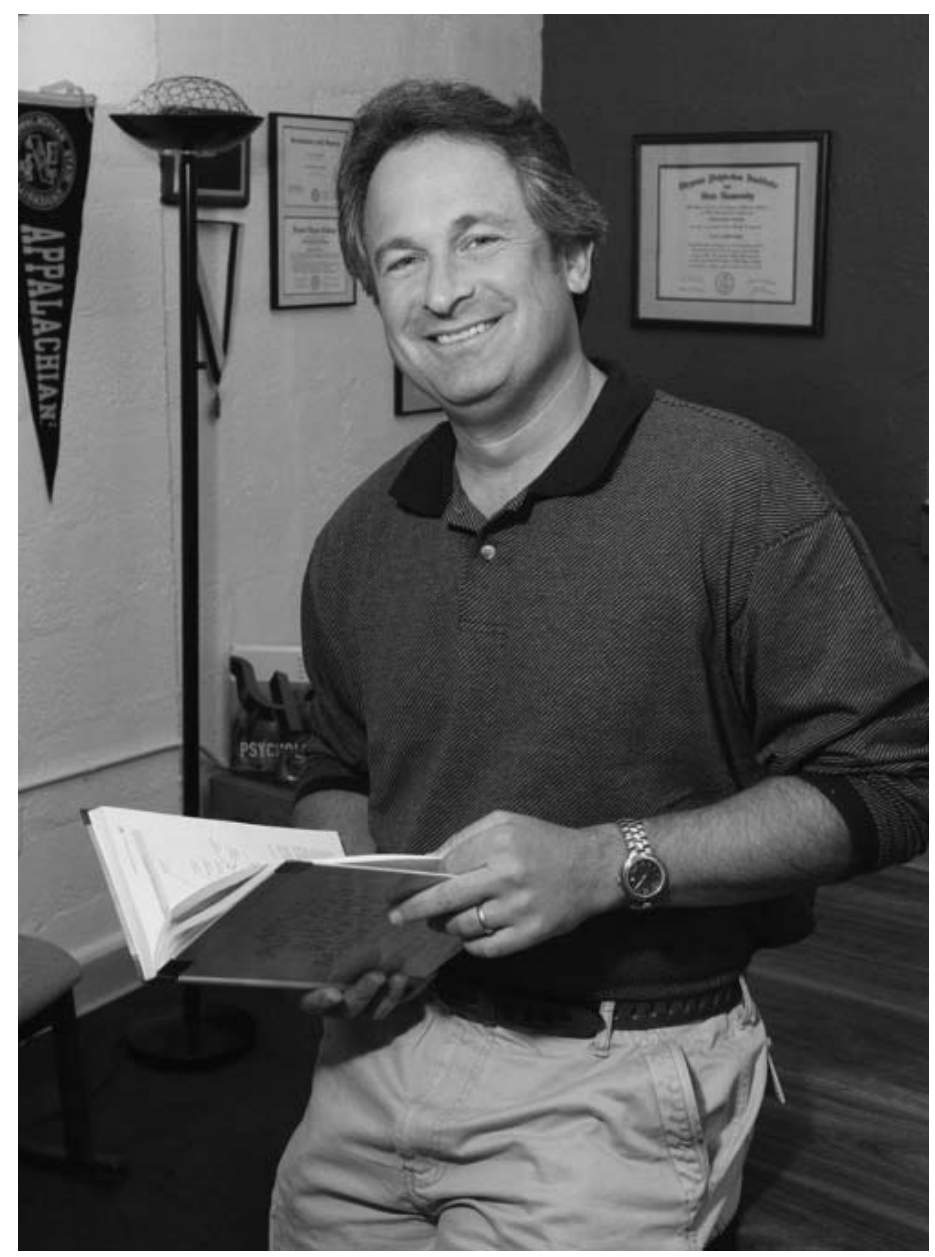

Timothy D. Ludwig

Tim: Once you made the decision to move to Plan $B$, did you have any idea of how things were going to turn out?

Tom: As a developmental psychologist, I believe it is very useful to plan carefully for each stage of life. But as my own life journey demonstrates, outside events in the form of obstacles or serendipitous opportunities often trump careful plans. When my original career plans to teach classical languages and study ancient manuscripts hit a snag in 1973, I entered graduate school in psychology with no way of knowing how favorable the outcome would be. But that decision, coupled with wonderful support from my colleagues over the years, has resulted in a very satisfying career.

Tim: The three of us have dedicated our lives to teaching, so let's talk about teaching styles. While I 
was an undergraduate at Lenoir-Rhyne University, I took several courses from my dad (Dave), and I always admired his teaching style. Tom, you also were in some of his classes when he was on faculty at Concordia College. Did he influence your own teaching?

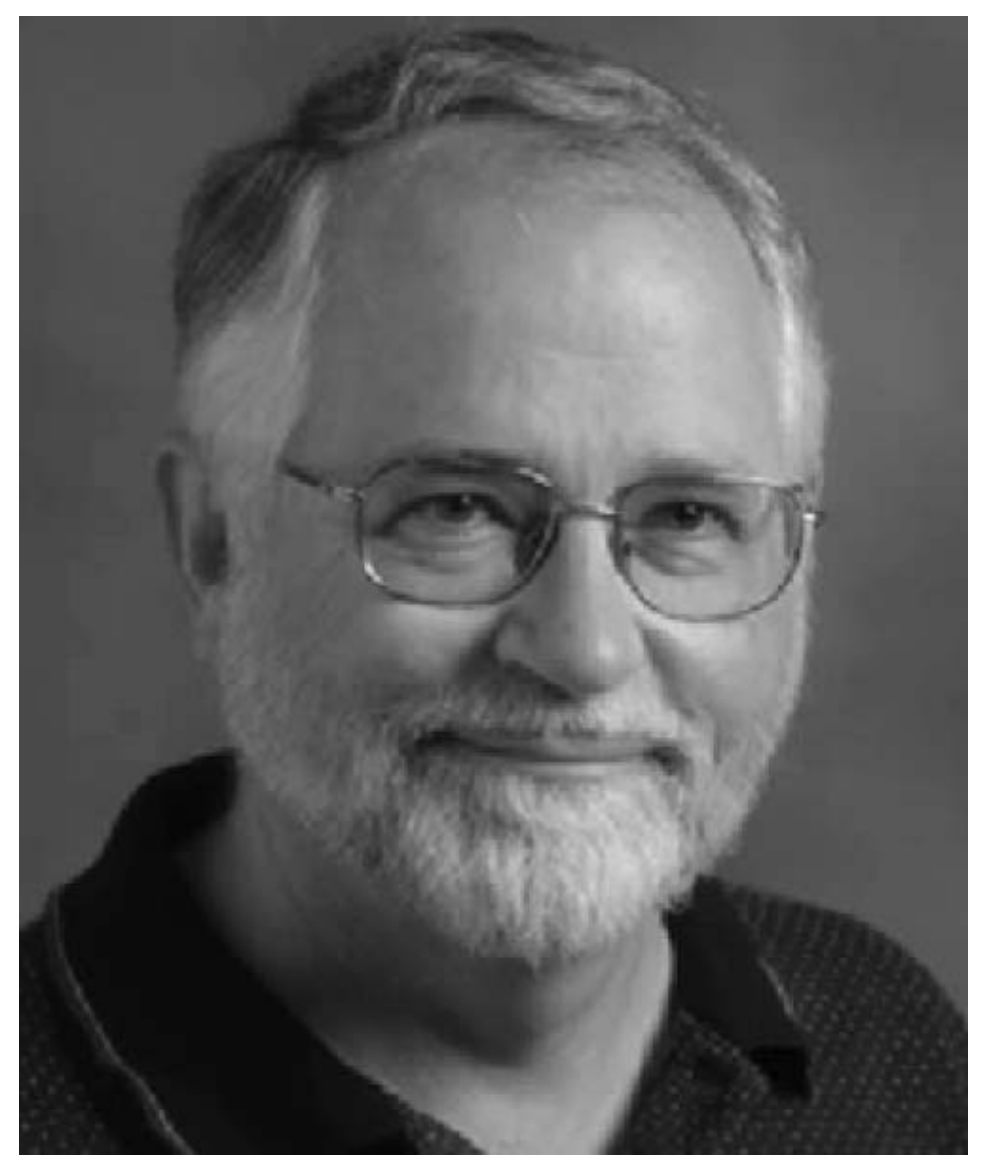

Thomas E. Ludwig

Tom: I definitely admired Dave's dynamic and provocative teaching style, but as I began my own teaching career, I realized I didn't have enough showmanship to be successful with that model. Instead, although I worked hard to become a good lecturer, I began to focus more on helping students learn through direct, practical applications of psychological principles. In developmental psychology, I turned my attention to supervising field placements and to observation reports. In introductory psychology, I tried to help students apply what they had learned through hands-on demonstration activities and by replicating classic experiments in and out of the classroom. 


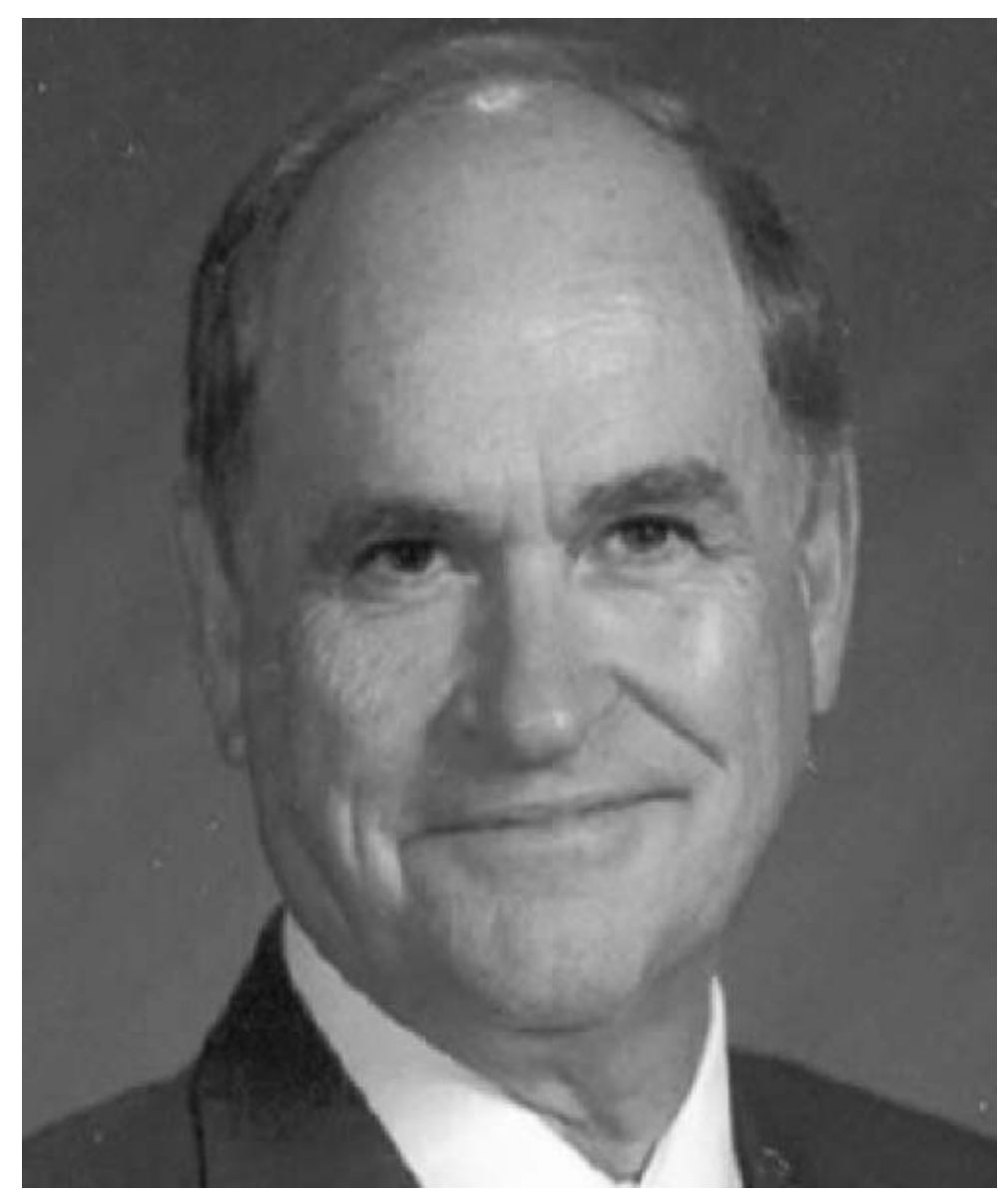

David J. Ludwig

Dave: Can you say a little more about what influenced your style of teaching?

Tom: In high school and college, I experienced a wide range of teaching styles and methods, and I noticed that some of those methods were more effective than others. Because I was already planning a career as an educator, I paid special attention to the techniques that seemed effective and filed this information away for future use. Unfortunately, what I learned from my high school teachers was what not to do while teaching, and I reacted against the methods and techniques they employed.

Tim: I felt the same way when I heard what my sons' high school teachers were doing in their classrooms. What about your college professors?

Tom: I had a much better experience in my college 
courses. I admired many of my professors, particularly those who were knowledgeable about their subjects, were well organized and well prepared for each class, made an effort to build rapport with students, went beyond the readings to draw connections and make applications, and planned opportunities for hands-on learning. Of course, I admired the rapport and enthusiasm my brother brought to his classroom lectures. It was harder to find hands-on demonstrations in those days, but I remember being impressed that Dave took the time to teach us how to run rats through a maze. Even though I had a "maze-dull" rat, it was certainly a memorable experience.

My college experiences influenced the way I reacted to my graduate school classes. Like most other graduate students inmy era, I had no formal training in teaching methods or classroom management. I learned the skills of teaching mainly by observing others and reflecting on my own teaching. During graduate school, I had several research mentors, but no teaching mentors. My research mentors, especially Martha Storandt and Jack Botwinick, impressed upon me the importance of personal integrity in all my professional activities and of balancing the various roles required of a professor. Tim: The issue of balance is an important one. New faculty members often struggle to balance the demands of the research lab and the classroom. What are your thoughts about the comparative benefits of publishing versus teaching and how to achieve a good balance?

Tom: That's a difficult question because both are essential. Research and scholarship are the lifeblood of our academic enterprise. Publishing promotes the exchange of ideas and facilitates progress in our field. So my advice to new faculty members-even those who are drawn to teaching - would be to take research seriously. Develop a research program that can add to existing knowledge about some interesting and important topic. This will advance your career and will provide practical examples that will enrich your teaching. But try to put equal effort into building your skills as a teacher. Across my decades as a professor, I've invested many thousands of hours in research, software development, and teaching. My published work has brought promotion and the respect of my colleagues, but these benefits are small compared to the personal rewards I've derived from teaching. 
Dave: That sounds refreshing. I know that you graduated in an era when publishing was definitely more important than teaching within most university systems. How did you overcome that mindset so that you could recognize the importance of good teaching? Tom: You're right. I think it was even harder to strike a balance between teaching and research in those years than it is now. As I interviewed at several schools in 1977, I learned that some university administrators of that era were not particularly interested in the teaching potential of faculty candidates. As one dean stated bluntly, "Good teachers are a dime a dozen. What we want is someone who can publish consistently and boost our national visibility." Although I was focused on my research program at the time, I found this message a bit discouraging, because I believed that good teaching was important, and I expected that I would become an effective teacher.

Tim: Is that what drew you to Hope College?

Tom: My interview at Hope College conveyed a different impression: Hope seemed to be a place where research was encouraged and supported, but good teaching was also valued highly. When I began my career at Hope, I learned that this initial impression was accurate. My faculty colleagues took teaching very seriously, and I realized immediately that I could learn a lot from them. For example, Jane Dickie helped me understand the important role of class discussions and showed me some effective techniques for nurturing small-group and full-class discussions. John Shaughnessy modeled techniques for pushing students to examine evidence and to think critically about psychological claims they encountered in the popular culture. Dave Myers encouraged me to add more visuals to my class presentations and also encouraged me to harness the power of computer technology in my teaching.

Dave: Because Hope College places a high value on teaching, did they provide any special training to help you succeed in the classroom?

Tom: Hope College now has a formal Teaching Enhancement Workshop for all new faculty members.

Unfortunately, the workshop was not available when I arrived in 1977. Each year, though, Hope's Pre-College Faculty Conference included an extensive program on teaching and learning. One especially influential session in the early 1980s featured the noted educator Parker Palmer, who helped me catch a broader vision of teaching as "creating a space" for learning, or more 
precisely, "creat[ing] a space in which obedience to truth is practiced" (Palmer, 1983, p. 69).

Tim: I'm reminded of when you were kind enough to be the keynote speaker at our Kulynych/Cline Teaching Festival a couple years ago at Appalachian State. l'd say you have been influential in your own right to the next generation of teachers.

Dave: Tom, I have watched your career with interest, and I am particularly gratified that you have become identified as an enthusiastic advocate for good teaching at Hope College and at the national level, especially in terms of the appropriate use of technology in teaching. What accomplishments are you most proud of in this area?

Tom: As you might expect, my skill as a teacher has increased considerably over my 32 years of professing psychology, and I'm proud of what students have learned under my guidance. Over those years, l've also learned a great deal about the use and misuse of computer technology in education, and it is that aspect of my career that has attracted the most attention. Most people know me primarily as a technology pioneer who has been using computer-assisted instruction in and out of the classroom since 1980. I'm proud of the reputation I've gained in this area, especially because it created opportunities to collaborate with others who share my interests. For example, in 2005, I coauthored two reports for the Society for the Teaching of Psychology's (STP) Pedagogical Innovations Task Force (Goolkasian, Ludwig, \& Froman, 2005; Ludwig, Daniel, Froman,\&Mathie, 2005); I also coauthored a chapter on this topic in the book Best Practices for Teaching Introduction to Psychology (Ludwig \& Perdue, 2005). I believe that my efforts in this area have been amply recognized, both by Hope College and by the American Psychological Foundation, which gave me their Charles L. Brewer Award for Distinguished Teaching of Psychology in 2005.

Tim: You mentioned some of your publications on teaching methods that are intended for instructors. What have you published that is specifically targeted toward students?

Tom: That has been a major part of my professional activity for the past 25 years. I have coauthored a dozen computerized study guides and an extensive multimedia resource for developmental psychology courses. I 
have also published six major instructional technology projects for introductory psychology.

Dave: I used your PsychSim package of computer activities inmy own introductory psychology classes for many years, so I'm very familiar with those activities. How is PsychSim different from your other instructional packages for introductory classes?

Tom: PsychSim was first published in 1986 as a package of 12 simulated experiments (Ludwig, 1986). It's now in its fifth edition and has grown to 42 activities (Ludwig, 2004). Basically, PsychSim activities are intended as supplemental homework assignments to accompany a standard classroom course. Each 15- to 20-minute activity provides concise guided instruction, with many animations and hands-on demonstrations, on a major topic in introductory psychology-such as classical conditioning or color vision. PsychQuest (Ludwig, 1997) activities are considerably longer (3040 minutes) and provide a more in-depth look at eight topics-depth perception in sports, psychoactive drugs, andmate selection, for instance-specifically chosen to appeal to the shrinking number of men who take introductory psychology. I designed PsychOnline (Ludwig, 2001) as a comprehensive solution for distance education courses, with more than 100 extensive tutorials replacing classroom lectures; the tutorials include hands-on demonstrations, mastery quizzing, and plenty of applications to international and multicultural issues. PsychInquiry (Ludwig, 2002) was an attempt to promote critical thinking through a guided investigation of 20 experiments.

All these packages were intended for individual student use outside the classroom, but in 2006, I coauthored amultimedia resource called ActivePsych, which I designed for in-class use (Ludwig et al., 2006). This way, instructors can provide high-interest demonstrations during their lectures. Finally, I've just spent 2 years developing Concepts in Action (Ludwig, 2008), a set of 109 brief and engaging activities that are being distributed through the PsychPortal learning management system. These activities are different from anything I've done before. Because these activities "pop out" from an electronic textbook page that provides the context for the topic, I didn't need to include screens of text that explained the background or interpreted the results of each demonstration. Instead, I could focus on what computer activities can do best-illustrate dynamic processes unfolding over time! 
Tim: You have been working with computer technology for a long time. Let's go back to the beginning and consider what influenced you to get involved with technology. I remember finding out early in my teaching career that I had some of the same abilities as my father, for example, the ability to motivate my students by lecturing in a way that made learning exciting and fun. Did you know right away that you could make learning exciting by focusing on individualized, practical application of the concepts through computer technology?

Tom: No, the idea of using computer technology in my classes didn't even occur to me back in 1977. It was difficult enough just to master the use of $16-\mathrm{mm}$ film projectors and slide projectors in the classroom. But a few years later, almost as a lark, I wrote my first instructional computer activity-and when I saw the way my students reacted, I was instantly converted. In spite of the pitiful graphics capability and slow speed of the computers of that era, I could already see that computer technology would have a major impact on education.

Dave: I want to go back to something you mentioned earlier: your perceived lack of showmanship at the start of your teaching career. Do you think this hurt your teaching, and if so, what did you do about it?

Tom: Although I believed that I had some natural abilities as a communicator, my first years of teaching did not go as smoothly as I had expected. I am basically a shy person, and I found that being "on stage" in front of students every day was quite stressful. I had been very comfortable in the role of student, but it took some time before I became comfortable in the professor's role. Because I had had no formal training as a teacher, I felt especially insecure about the particular methods I used. I tried to improve my skills and my classroom presence by reading books and articles on effective teaching. Fortunately, I was able to attend a number of workshops on teaching, including several National Institute on the Teaching of Psychology (NITOP) conferences and a very useful Pew Foundation conference at Carleton College. Tim: Being "on stage" was fairly easy for me, but that is only one part of what a teacher does. Did you run into any problems or frustrations with other aspects of your teaching? 
Tom: Early in my teaching career, I also struggled with issues related to course organization and planning, particularly with the issue of how much content to cover in each class session. I also found it difficult to strike the right balance among lecture, discussion, and demonstration activities. I settled those issues to my satisfaction after about 10 years of teaching, but other issues, such as finding appropriate methods to evaluate student performance, continued into my second decade of teaching.

Dave: I had some of those same frustrations. I must admit that I was not good at evaluating student performance, nor did I enjoy it. How did you resolve those issues?

Tom: Even now, I occasionally wonder whether I am doing a fair job of grading student papers and lab reports. But I no longer agonize over the choice of evaluation methods for each course, because I have formulated an evaluation system that is keyed to the developmental status of my students as well as to the objectives of the courses I teach. In my first-year introductory psychology course, I administer five exams consisting of multiple-choice questions to assess recognition familiarity with the major principles of psychology and research findings. I also use lab reports to assess understanding of basic research methodology. In my developmental psychology course, a second-year course, I use four exams containing a combination of multiple-choice questions and essay questions to test comprehension of course content; I also use journal entries to assess performance in an off-campus field placement. In my third-year seminar on adult development and aging, I use two essay exams combined with oral presentations and a literature review paper. Finally, in my senior seminar course, there are no exams. Instead, students write integrative essays, make substantial oral presentations, and write a 30-page paper. Tim: That sounds great. I admire your ability to key the type of evaluation to the developmental status of the student. I think I can learn something there! But I want to know how you balance all the things you do. Right now l'm struggling to balance consulting work, editing a journal, writing, teaching, and having a personal life.

Tom: You're right. It all comes down to balance. I also struggle tomaintain an appropriate balance among teaching, research, and service (e.g., advising, committee work, and leadership roles in my community 
and academic discipline). In particular, I feel a definite tension between teaching and service. During advising week, I have a great deal of difficulty keeping up with my classes, and committee work definitely cuts into my time for teaching preparation and grading.

Tim: We've talked about this already, but I noticed that you did not say "teaching versus research." Tom: At Hope, there is perhaps less conflict between teaching and research than at some other institutions. Empirical research and other scholarly activities are definitely valued and rewarded at Hope, but much of my research has been done in the context of mentoring upper level undergraduate students, so it really became an extension of my teaching rather than something that competed with it. At Hope, the psychology professors take turns teaching an advanced research laboratory course for which they get teaching credit for doing research in collaboration with a team of undergraduate students.

Dave: I have now retired but still teach an intensive graduate course on the spiritual dimension of counseling. As I reflect on my teaching career, I realize that there are some general teaching principles that have guided my work as a professor. Could you identify what principles inform your teaching?

Tom: I've thought about this a lot, Dave. Across the years, it seems that three basic principles have guided my decisions about what to teach, how to teach, and how to interact with my students. The first is integrity. I've tried hard to be honest and fair with my students and to teach what I really believe to be true about human behavior. The second is humility. I've tried to remind myself and my students that there is a great deal we don't yet know about human behavior and that any one person's knowledge and insight are limited. The final principle is common purpose. I've tried to engage my students in the shared pursuit of knowledge and understanding and to help them see that we are on the same team.

Tim: As you look back across your teaching career, I am interested in how your teaching style has changed. I know that my own style has changed somewhat with the increased availability of technology.

Tom: The field of psychology has evolved over the decades during which l've been teaching, and my teaching style has also evolved as l've learned more about psychology and more about teaching. I don't 
want to exaggerate, but I believe that some of the changes in my teaching style have been significant. Here are four examples.

The first change entailed a shift in the balance of lecture and discussion I use within each class session. From the beginning of my career, I have tried to include occasional class discussions, but over the years I've increased the frequency of these discussions. In a typical course, I include several extended discussion periods on controversial topics. I also include briefer discussions, lasting anywhere from 2 to 4 minutes, that focus on the application of principles we are covering in class. The second change has been a steady increase in my use of technology in the classroom. During my first 2 decades of teaching, I progressively moved from the chalkboard to media technology that included filmstrips, slides, overhead transparencies, 16-mm movies, videotapes, videodiscs, PowerPoint lecture outlines, CD-ROMs, and DVDs. I'm now moving to class sessions centered around digitally projected video clips and interactive animations programmed in Flash. The third change was a steady increase in my use of technology in homework assignments. In the 1980s, as I became heavily involved in developing instructional computer activities, I gained respect for the power of computer technology as an aid to instruction, and that respect has grown over the past 2 decades. I now frequently assign computer activities that simulate classic experiments or demonstrate complex principles in a self-paced interactive format. Finally, I've shifted from "covering material" to "problem-based learning" as the focus of each class session. I'm still in the midst of this transition, but it has already had a major impact on my teaching and the way I see my role as an instructor.

Dave: Rewards and frustrations are definitely a part of my teaching career. Could you reflect on some of the rewarding times and some of the frustrating times?

Tom: I've derived substantial rewards from my career as a psychology professor. Perhaps the greatest rewards come from my contact with students-seeing "the light come on" as they catch the excitement of studying human behavior and then, in the case of our graduate schoolbound students, mentoring them as they prepare for careers as professional psychologists. I've also appreciated the opportunity to consider and develop new ideas about behavior and discussing those ideas with my colleagues at Hope and at professional conferences. 
It's difficult to imagine another career that would be as satisfying as the one I have. But even the best job has times of disappointment and frustration. My greatest frustrations have involved time pressure - the constant deadlines for preparing lectures and exams and grading papers. I often feel that, given more time, I could have done more to prepare for a class session or could have spent more time giving feedback on student papers. I've also been frustrated and disappointed by individual students who didn't connect with the course material. Fortunately, the new course management technology allows me to keep closer tabs on the progress of each student and to intervene sooner when a student's performance begins to falter.

Tim: What do you have to say to psychology professors like myself who really want to continue learning and growing in the teaching of psychology? Tom: I believe that every professor, even those who are seasoned instructors, can find ways to improve. A good place to start would be to explore the many resources available online through the STP Web site (http://teachpsych.org). But the bottom line is that you've got to keep pushing yourself; improvement won't happen unless you invest some effort. I spend a lot of time preparing for my courses and reflecting on what l've learned from each course. For me, an important part of this process is collecting student evaluations at midterm and at the end of the course. After 60 semesters of evaluations, I can predict how most students will respond to the course and to me as a teacher. But I always learn something new from each set of evaluations, and they always make me think about ways I could improve my teaching.

I've also benefited from having peers periodically observe my teaching. Although it takes courage to invite a colleague to class, I've gained valuable new insights both from senior faculty members and from my new colleagues who are fresh out of graduate school.

Dave: We've been talking about continuing growth in one's teaching career. What advice would you give to those just starting out as new teachers?

Tom: If there is anything I've learned from 30 years of teaching, it is that there is no magic recipe that will make someone a good teacher. There are many pathways to teaching effectiveness; there are also many ways to fail. I believe that new faculty members need to evaluate their strengths and weaknesses as communicators, 
motivators, and classroom administrators and then find their own unique path to teaching success. I highly recommend seeking advice from, and perhaps observing, instructors who have a passion for teaching-they can be found in every college and university. I also believe that I have learned a lot from reflecting on my own teaching (see Ludwig, 2005). With suitable humility, I offer these suggestions: Effective teaching requires consistent effort, even on those days when it's hard to get motivated. Effective teaching requires planning and organization, coupled with enough flexibility to enable on-the-spot changes to capture the "teachable moment." Effective teachers convey enthusiasm and have good communication skills-every lecturer could benefit from some time with a speech or drama coach. Effective teachers maintain high expectations-they set high standards for themselves and for their students and hold everyone accountable. Effective teachers make appropriate use of technology. Finally, effective teachers never stop learning.

Tim: Those are some good thoughts, Tom. Thanks for sharing them with us.

\section{Resources}

Goolkasian, P., Ludwig, T. E., \& Froman, R. (2005). Software tools in the teaching of psychology: Best resources list. Retrieved April 27, 2009, from the Society for the Teaching of Psychology Web site: http://teachpsych.org/resources/pedageeogy/bestlists.pdf

Ludwig, T. E. (1986). PsychSim: Interactive graphic simulations for psychology. New York: Worth.

Ludwig, T. E. (1997). PsychQuest. New York: Worth.

Ludwig, T. E. (2001). PsychOnline: A comprehensive resource for distance education in psychology. New York: Worth.

Ludwig, T. E. (2002). Psychlnquiry: Student activities in research and critical thinking. New York: Worth.

Ludwig, T. E. (2004). PsychSim 5: Interactive simulations for introductory psychology. New York: Worth.

Ludwig, T. E. (2005). Ten things l've learned from teaching psychology. Retrieved April 27, 2009, from http://www. hope.edu/academic/psychology/ludwig/TenThings.pdf 
Ludwig, T. E. (2006). Living, learning, teaching. In J. G. Irons, B. C. Beins, C. Burke, B. Buskist, V. Hevern, \& J. E. Williams (Eds.), The teaching of psychology in autobiography: Perspectives from exemplary psychology teachers (Vol. 2, chap. 9). Retrieved April 27, 2009, from the Society for the Teaching of Psychology Web site: http://teachpsych. org/resources/e-books/tia2006/pdf/12.pdf

Ludwig, T. E. (2008). Concepts in action. New York: Worth.

Ludwig, T., Bolt, M., Morrisey, J., Look, K., Miller, A., Epstein, E., Valenti, S., Merriwether, A., Alexander, R.,

Lambert, K., Peluso, J., Peck, A., Sambrook, R., Bach, M., \& Obegi, A. (2006). ActivePsych: Classroom activities and video teaching modules. New York: Worth.

Ludwig, T. E., Daniel, D. B., Froman, R., \& Mathie, V. A. (2005). Using multimedia in classroom presentations: Best principles. Retrieved April 27, 2009, from Society for the Teaching of Psychology Web site: http://teachpsych. org/resources/pedagogy/classroommultimedia.pdf

Ludwig, T. E., \& Perdue, C. W. (2005). Multimedia and computer-based learning in introductory psychology. In D. S. Dunn \& S. L. Chew (Eds.), Best practices for teaching introduction to psychology (pp. 143-158). Mahwah, NJ: Lawrence Erlbaum Associates, Inc.

Palmer, P. J. (1983). To know as we are known: Education as a spiritual journey. San Francisco: Harper.

\section{Notes}

1. Portions of this interview are based on material from an essay written by Thomas Ludwig (Ludwig, 2006).

2. Send correspondence to Timothy D. Ludwig, Appalachian State University, Department of Psychology, Boone, NC 28606; e-mail: ludwigtd@appstate.edu. 